\section{Nutrient Cycling, Weed Suppression, and Onion Yield Following Brassica and Sorghum Sudangrass Cover Crops}

\author{
Guangyao Wang ${ }^{1}$, Mathieu Ngouajio ${ }^{1,3}$, and Darryl D. Warncke ${ }^{2}$
}

AdDitional Index wORDs. Allium cepa, biofumigants, cropping systems, muck soils, mustards, sustainable agriculture

\begin{abstract}
SumMARY. The effects of cover crops on nutrient cycling, weed suppression, and onion (Allium cepa) yield were evaluated under a muck soil with high organic matter in Michigan. Four brassica cover crops, including brown mustard (Brassica juncea 'Common brown'), oilseed radish (Raphanus sativus 'Daikon'), oriental mustard (B. juncea 'Forge'), and yellow mustard (Sinapis alba 'Tilney'), as well as sorghum sudangrass (Sorghum bicolor $\times$ S. sudanense 'Honey Sweet') produced similar amount of biomass and recycled similar amounts of nitrogen, phosphorus, and potassium. The brassica cover crop biomass contained more calcium, sulfur, and boron, but less magnesium, iron, manganese, copper, and zinc than sorghum sudangrass. However, soil fertility was generally similar regardless of whether a cover crop was used. This was mainly because the soil was sampled when most of the cover crop residue was not yet decomposed. Weed density during onion growth was reduced by all cover crops compared with the control with no cover crop, with yellow mustard treatment having the lowest weed density among the cover crops. Weed species composition was also significantly affected by the cover crops. Yellow mustard treatment had the lowest density of common purslane (Portulaca olevacea) and redroot pigweed (Amaranthus retroflexus), whereas sorghum sudangrass had the highest yellow nutsedge (Cyperus esculentus) density among all the treatments. However, weed suppression was not enough to eliminate normal control strategies. The brassica cover crops, especially oilseed radish and yellow mustard, increased onion stand count and marketable yield. These results suggest that brassica and sorghum sudangrass cover crops could provide multiple benefits if incorporated into short-term onion rotations under Michigan growing conditions.
\end{abstract}

$\mathrm{T}$ The Michigan onion industry was valued at $\$ 9.65$ million in 2005 , with a total of 1500 ha harvested (Michigan Department of Agriculture, 2006). Most of the production is for fresh market and is conducted mainly on muck soils. The high organic matter and nutrient content of these soils help produce high-quality vegetables. Therefore, commercial onion production in Michigan is conducted under intensive systems with short-term crop rotations. Many onion growers use a 2- to 3-year rotation with crops like celery (Apium graveolens), carrot

This research was funded in part by Project GREEEN (Generating Research and Extension to meet Environmental and Economic Needs) no. GR03-016, Michigan Onion Research Committee, and the Michigan Vegetable Council.

We acknowledge technical help from Ron Gnagey, Erin Hill, James Counts, Saidi Mwanarusi, and Ajay Nair.

${ }^{1}$ Department of Horticulture, Michigan State University, 428 Plant and Soil Sciences, East Lansing, MI, 48824

${ }^{2}$ Department of Crop and Soil Science, Michigan State University, East Lansing, MI 48824

${ }^{3}$ Corresponding author. E-mail: ngouajio@msu.edu.
(Daucus carota), field corn (Zea mays), or potatoes (Solanum tuberosum). With the exception of field corn, most of those crops leave low residues after harvest. As a consequence of these cropping systems, cultivated muck soils may subside up to $3 \mathrm{~cm}$ every year because of wind erosion, compaction, and organic matter oxidation (Hoffmann et al., 1996). A cover crop planted after harvest of the cash crop may help reduce soil erosion and compaction
(Hoffmann et al., 1996). Cover crops and other soil organic amendments could also serve as enhancement strategies for onion production under short-term crop rotations. Benefits could include weed suppression (Boyhan et al., 2006; Charles et al., 2006; Liebman and Gallandt, 1997), reduced nitrate leaching (Corak et al., 1991; Greenwood et al., 1996; Hall et al., 1984), and improved yield (Boydston and Hang, 1995; Krishnan et al., 1998; Thorup-Kristensen, 2006).

Barley (Hordeum vulgare) has been used successfully in many regions as a living mulch with onions to reduce soil erosion and to protect the onions from wind damage (Greenland, 2000; Hatterman-Valenti and Hendrickson, 2006; Zandstra and Warncke, 1993). However, few studies have looked at the effect of the preceding cover crop on onion production. In a recent study conducted in Denmark, Thorup-Kristensen (2006) showed that nitrogen $(\mathrm{N})$ uptake by onion was enhanced in plots with a previous cover crop compared with control plots. The amount of nutrients recycled by cover crops and released during the decomposition process is important information that could be used to coordinate the nutrients available and nutrient uptake of cash crops (Rosecrance et al., 2000). This could reduce fertilizer input and nutrient leaching while maintaining desirable crop yield.

In Michigan, onions are usually seeded in April and harvested in September. The long growing season does not provide an adequate window to grow warm-season cover crops. Fall-seeded winter cover crops like wheat (Triticum aestioum) and cereal rye (Secale cereale) are the most common species used by growers in

\begin{tabular}{llll}
\hline $\begin{array}{l}\text { Units } \\
\begin{array}{l}\text { To convert U.S. to SI, } \\
\text { multiply by }\end{array}\end{array}$ & U.S. unit & SI unit & $\begin{array}{l}\text { To convert SI to U.S., } \\
\text { multiply by }\end{array}$ \\
\hline 0.4047 & $\mathrm{acre}(\mathrm{s})$ & $\mathrm{ha}$ & 2.4711 \\
0.3048 & $\mathrm{ft}$ & $\mathrm{m}$ & 3.2808 \\
0.0929 & $\mathrm{ft}^{2}$ & $\mathrm{~m}^{2}$ & 10.7639 \\
2.54 & inch $(\mathrm{es})$ & $\mathrm{cm}$ & 0.3937 \\
25.4 & inch $(\mathrm{es})$ & $\mathrm{mm}$ & 0.0394 \\
1.1209 & $\mathrm{lb} / \mathrm{acre}$ & $\mathrm{kg} \cdot \mathrm{ha}^{-1}$ & 0.8922 \\
1 & meq $/ 100 \mathrm{~g}$ & $\mathrm{cmol} \cdot \mathrm{kg}^{-1}$ & 1 \\
1 & micron & $\mu \mathrm{m}$ & 1 \\
28.3495 & $\mathrm{oz}$ & $\mathrm{g}$ & 0.0353 \\
305.1517 & $\mathrm{oz} / \mathrm{ft}^{2}$ & $\mathrm{~g} \cdot \mathrm{m}^{-2}$ & 0.0033 \\
1 & $\mathrm{ppm}$ & $\mathrm{mg} \cdot \mathrm{kg}^{-1}$ & 1 \\
2.2417 & ton $/ \mathrm{acre}$ & $\mathrm{t} \cdot \mathrm{ha}^{-1}$ & 0.4461 \\
$\left({ }^{\circ} \mathrm{F}-32\right) \div 1.8$ & ${ }^{\circ} \mathrm{F}$ & ${ }^{\circ} \mathrm{C}$ & $\left(1.8 \times{ }^{\circ} \mathrm{C}\right)+32$
\end{tabular}


Michigan. The cover crop is usually killed late in the spring by cultivation or by herbicide application, followed by crop planting (Mutch and Martin, 1998). The large amount of biomass produced and its slow decomposition make those cover crops unsuited for onion production in Michigan, because most of the onion in Michigan is direct seeded and requires a wellprepared seedbed for adequate seed emergence and establishment. Many onion growers are interested in improving their short-term crop rotations with cover crops that do not interfere with field operations at the time of onion seeding. Cool-season cover crops like brassicas could be integrated in the crop rotation systems and planted in the fall after harvest of a short-cycle crop. Their residues break down easily and do not interfere with field operations in the spring (Charles et al., 2006). Several studies showed that brassica species suppressed seed germination, emergence, and seedling growth of many weed species in the laboratory, greenhouse, and field studies (Al-Khatib et al., 1997; Boydston and Hang, 1995; Krishnan et al., 1998; Haramoto and Gallandt, 2004). Brassica cover crops are also known to produce glucosinolates, which upon hydrolysis release biocidal compounds, including isothiocyanates, with activity on phytophagous insects, nematodes, and fungi (Brown and Morra, 1996; Haramoto and Gallandt, 2004, 2005; Matthiessen and Kirkegaard, 2006; Mojtahedi et al., 1991). This study was therefore undertaken to determine the effects of several brassica cover crops and sorghum sudangrass on nutrient cycling, weed suppression, and onion yield.

\section{Materials and methods}

Experiments were conducted at Michigan State University Muck Soils Research Farm in Laingsburg, MI (lat. $42^{\circ} 53^{\prime} 25^{\prime \prime} \mathrm{N}$, long. $84^{\circ} 21^{\prime} 4^{\prime \prime} \mathrm{W}$ ), from 2004 to 2006 on a Houghton muck soil with a $\mathrm{pH}$ of 6.5 and $80 \%$ organic matter. Mean weekly temperature and precipitation during onion growth in 2005 and 2006 (April to September) are shown in Table 1.

The experiment used a randomized complete block design with four replications and six treatments: five cover crops and a bare-soil control. The five cover crops included 'Honey
Table 1 . Mean weekly temperature and precipitation in Laingsburg, MI, during onion growth in 2005 and $2006 .{ }^{2}$

\begin{tabular}{|c|c|c|c|c|}
\hline \multirow{2}{*}{$\begin{array}{l}\text { Time after } \\
\text { sowing } \\
\text { (weeks) }\end{array}$} & \multicolumn{2}{|c|}{$\begin{array}{l}\text { Weekly avg } \\
\text { temp } \\
\left({ }^{\circ} \mathrm{C}\right)^{\mathrm{y}}\end{array}$} & \multicolumn{2}{|c|}{$\begin{array}{c}\text { Weekly } \\
\text { rainfall } \\
(\mathrm{mm})^{y}\end{array}$} \\
\hline & 2005 & 2006 & 2005 & 2006 \\
\hline 1 & 5.4 & 10.8 & 0.0 & \\
\hline 2 & 13.5 & 12.9 & 4.8 & 0 . \\
\hline 3 & 11.0 & 11.8 & 17.3 & 77 \\
\hline 4 & 12.4 & 9.8 & 3.6 & 14 \\
\hline 5 & 14.2 & 21.3 & 8.4 & 38 \\
\hline 6 & 22.8 & 18.2 & 16.0 & 10. \\
\hline 7 & 22.0 & 15.9 & 31.3 & \\
\hline 8 & 16.5 & 20.9 & 0.0 & 20. \\
\hline 9 & 25.2 & 18.8 & 7.4 & 35. \\
\hline 10 & 19.5 & 20.1 & 0.3 & 5 \\
\hline 11 & 21.9 & 19.0 & 14.2 & 32. \\
\hline 12 & 23.3 & 23.0 & 22.1 & 28. \\
\hline 13 & 22.0 & 20.7 & 34.5 & 0 . \\
\hline 14 & 21.6 & 25.3 & 24.1 & 114. \\
\hline 15 & 21.9 & 22.1 & 13.5 & 49. \\
\hline 16 & 21.1 & 18.6 & 14.2 & 0 \\
\hline 17 & 17.5 & 19.7 & 13.2 & 2. \\
\hline 18 & 20.1 & 20.3 & 16.0 & 27. \\
\hline 19 & 18.2 & 16.6 & 8.9 & 0. \\
\hline 20 & 19.5 & 16.6 & 13.5 & 24. \\
\hline 21 & & 16.6 & & 16. \\
\hline
\end{tabular}

${ }^{\mathrm{z}}$ Onions were sown on 29 Apr. 2005 and 26 Apr. 2006, and harvested on 15 Sept. 2005 and 18 Sept. 2006.

${ }^{\mathrm{y}}\left(1.8 \times{ }^{\circ} \mathrm{C}\right)+32={ }^{\circ} \mathrm{F}, \mathrm{l} \mathrm{mm}=0.0394$ inch.

sweet' sorghum sudangrass and four brassica species, including 'Common brown' brown mustard, 'Daikon' oilseed radish, 'Forge' oriental mustard, and 'Tilney' yellow mustard.

Cover crop seeds were broadcast using a hand spreader on 18 Aug. 2004 and 9 Aug. 2005. The seeding rates were $60,20,12,12$, and $12 \mathrm{lb} /$ acre for sorghum sudangrass, oilseed radish, oriental mustard, yellow mustard, and brown mustard respectively. Weeds in all the treatments, including the control with no cover crop, were not controlled during cover crop growth. The cover crops were sampled on 5 Oct. 2004 and 5 Oct. 2005 for biomass production and nutrient content when all brassica cover crops were still alive and actively growing (sorghum sudangrass was previously killed by freezing temperatures on 18 Sept. 2004 and 27 Sept. 2005). A $50 \times 50-\mathrm{cm}$ quadrat was tossed in each plot and all whole cover crop plants (above- and below-ground parts) were collected. Samples were dried to constant weight before biomass determination. Cover crop residue was incorporated into the soil immediately after sampling. The field was sprinkler irrigated immediately after incorporation to seal the soil surface and keep chemicals released by crop residues in the soil. This is a recommended practice to enhance the biofumigation effects of brassica cover crops (Matthiessen and Kirkegaard, 2006). No other field operation was conducted throughout the winter period.

In the spring (mid April), a composite soil sample with 10 soil cores (0-15-cm depth) was randomly taken in each plot. Soil from each plot was then mixed for nutrient and weed seedbank analyses. Weed seeds in a sample of $200 \mathrm{~g}$ dry soil from each plot were separated from the soil by passing the soil-water slurry through a sieve with a $250-\mu \mathrm{m}$ mesh size (Gross, 1990). The total number of weed seeds in each sample was recorded. It is important to note that weed seed viability was not tested.

After soil sampling, the entire field received a starter fertilizer that supplied $35 \mathrm{~kg} \cdot \mathrm{ha}^{-1} \mathrm{~N}, 40 \mathrm{~kg} \cdot \mathrm{ha}^{-1}$ phosphorus $(\mathrm{P})$, and $120 \mathrm{~kg} \cdot \mathrm{ha}^{-1}$ potassium $(\mathrm{K})$. Onion was direct seeded in three double rows per bed on 29 Apr. 2005 and 26 Apr. 2006. Individual plots were $15 \times 25 \mathrm{ft}$ with two beds (12 rows total). Spacing between the two beds was $5.5 \mathrm{ft}$, and spacing between beds from consecutive treatments was $9.5 \mathrm{ft}$. The extra 4 -ft buffer between treatments was to account for cover crop residue movement during tillage operations. Spacing between the consecutive double rows on the same bed was $1.4 \mathrm{ft}$, and spacing between the two rows in each double row was 5 inches. The corresponding planting density was 285,000 seeds/acre. The onion crop was irrigated as needed to eliminate any drought stress.

Two weeks after emergence, onion stand was measured to determine the effect of the cover crops on onion germination in 2006. The weed control program followed normal recommendation for onion production on muck soil in Michigan (Zandstra, 2005). Preemergent pendimethalin at $2.2 \mathrm{~kg} \cdot \mathrm{ha}^{-1}$ a.i. (Prowl; BASF Corp., Research Triangle Park, NC) was applied on 9 May 2005 and 4 May 2006, postemergent oxyfluorfen at $0.07 \mathrm{~kg} \cdot \mathrm{ha}^{-1}$ a.i. (Goal; 
Dow AgroSciences, Indianapolis, IN) was applied on 10 June 2005 and 5 June 2006, plus an additional postemergent pendimethalin at $2.2 \mathrm{~kg} \cdot \mathrm{ha}^{-1}$ a.i. was applied on 16 June 2005 . Additionally, plots were hand weeded as needed. A randomly selected area of $1 \times 0.5 \mathrm{~m}$ on one of the onion beds in each plot was marked each year for assessment of the effect of cover crops on weed populations. This area was covered with plastic mulch during herbicide applications. These sites were selected before weed emergence to avoid any sampling bias and were permanent during each of the growing seasons. Weed evaluations were conducted on 23 June and 7 July in 2005 , and 26 June and 10 July in 2006 . Weeds were counted by species, and then dried to constant weight for biomass measurement. Microplots used for weed evaluation were not harvested, and therefore weed competition from those sites did not affect onion yield evaluations.

Onion was harvested on 15 Sept. 2005 and 18 Sept. 2006 on a section of $2 \mathrm{~m}$ of one bed in each plot. Onions were removed and stored in the shade for 2 weeks and then sorted into grades $1,2,3$, and 4 according to local market standards adapted from U.S. Department of Agriculture standards (U.S. Department of Agriculture, 1995). Grades 1, 2, 3, and 4 consisted of bulbs with a diameter of 0 to 2 inches, 2 to 2.5 inches, 2.5 to 3 inches, and more than 3 inches respectively. The number of bulbs in each grade was recorded and the weight of each grade was measured.

Analysis of variance (ANOVA) was used to detect year and treatment effects. When there was no significant treatment-by-year interaction, data for the 2 years and data on that specific variable were combined. The ANOVA procedure in SAS (SAS Institute, Cary, NC) was used to compare the treatments. All means were separated by Fisher's protected LSD at a probability level of 0.05 .

\section{Results}

Nutrient CyCling by the COVER CROPS. Biomass production was similar among cover crops. All species produced 6 to $8 \mathrm{t} \cdot \mathrm{ha}^{-1}$ dry biomass on average (Table 2). The cover crops also cycled similar amounts of $\mathrm{N}, \mathrm{P}$, and $\mathrm{K}$. However, there were significant differences in magnesium $(\mathrm{Mg})$, calcium $(\mathrm{Ca})$, sulfur $(S)$, and micronutrients among cover crops. Sorghum sudangrass had higher $\mathrm{Mg}$ but lower $\mathrm{Ca}$ and $\mathrm{S}$ content than brassica species. For micronutrients, sorghum sudangrass had higher iron (Fe), manganese, copper, and zinc, but lower boron than brassica species.

The cover crops did not affect soil nutrients except $\mathrm{P}$, with oilseed radish plots showing higher values than other cover crop species (Table 3 ). There was no difference among treatments for cation exchange capacity.

Weed populations. All brassica cover crop treatments had lower weed density at each of the two sampling dates than the control treatment (Table 4). Sorghum sudangrass reduced weed density significantly only at the second sampling date. All cover crops reduced total weed, with yellow mustard having the greatest effect. Generally, weed biomass followed the same pattern as weed density. This suggests a possible adjustment of weed growth in response to differences in density. Yellow mustard was the most effective cover crop at suppressing weeds, with $52.6 \%$ and
$31.5 \%$ reduction in weed density and weed biomass respectively when compared with the control.

Yellow nutsedge, common purslane, redroot pigweed, and wild mustard (Brassica kaber) represented more than $90 \%$ of the total weed populations in the field (Table 5). The cover crops significantly affected weed species composition. Redroot pigweed populations were more affected by the cover crops than any other weed species. Control treatment had the highest density of common purslane and pigweed (two major weeds in the control plot during cover crop growth), whereas the yellow mustard treatment had the lowest density of these two weed species. Sorghum sudangrass had higher yellow nutsedge density compared with the control and brassica cover crop treatments, except for the brown mustard treatment. Wild mustard was unaffected by the cover crops, probably because of their close relationship with the brassica cover crops used. Also, wild mustard is a winter annual and did not produce any seed in the fall before incorporating the cover crops in October.

All cover crops reduced recoverable weed seeds in the soil compared with control treatment (Fig. 1). Weed seeds in the cover crop plots were at least threefold lower compared with the control system. This suggests that under our experimental conditions, weed populations in the preceding season are critical for weed seedbank recruitment. The cover crops suppressed most weed species and reduced seed production in the late summer and early autumn.

ONION STAND AND BULB YIELD. Oilseed radish, yellow mustard, and brown mustard treatments had

Table 2. Total nutrient content (above- and below-ground plant parts) of the cover crops used for onion production in Laingsburg, MI, before incorporation into the soil in 2005 and $2006 .^{\mathrm{z}}$

\begin{tabular}{|c|c|c|c|c|c|c|c|c|c|c|c|c|c|}
\hline \multirow[b]{2}{*}{ Cover crop } & \multirow{2}{*}{$\begin{array}{c}\text { Biomass } \\
\left(\mathrm{kg} \cdot \mathrm{ha} \mathrm{a}^{-1}\right)^{\mathrm{z}}\end{array}$} & \multicolumn{12}{|c|}{ Total nutrient content $\left(\mathrm{kg} \cdot \mathrm{ha} \mathrm{a}^{-1}\right)^{\mathrm{z}}$} \\
\hline & & $\mathbf{N}$ & $\mathbf{P}$ & $\mathbf{K}$ & Mg & $\mathrm{Ca}$ & $S$ & $\mathbf{N a}$ & $\mathrm{Fe}$ & Mn & $\mathbf{B}$ & $\mathrm{Cu}$ & $\mathrm{Zn}$ \\
\hline istard & $6136 \mathrm{a}^{\mathrm{y}}$ & $276.0 \mathrm{a}$ & $30.3 \mathrm{a}$ & $364.5 \mathrm{a}$ & $15.8 \mathrm{~b}$ & $181.2 \mathrm{a}$ & $46.8 \mathrm{a}$ & $8.7 \mathrm{~b}$ & $2.6 \mathrm{~b}$ & $0.10 \mathrm{~b}$ & $0.18 \mathrm{~b}$ & $0.05 \mathrm{~b}$ & $0.24 \mathrm{ab}$ \\
\hline Oriental mustard & $8234 \mathrm{a}$ & $349.1 \mathrm{a}$ & $34.9 \mathrm{a}$ & $419.1 \mathrm{a}$ & $21.6 \mathrm{~b}$ & $227.6 \mathrm{a}$ & $52.8 \mathrm{a}$ & $15.9 \mathrm{~b}$ & $6.6 \mathrm{~b}$ & $0.21 \mathrm{~b}$ & $0.23 \mathrm{a}$ & $0.08 \mathrm{~b}$ & $0.22 \mathrm{~b}$ \\
\hline Yellow mustard & $7092 \mathrm{a}$ & $277.4 \mathrm{a}$ & $28.5 \mathrm{a}$ & $401.2 \mathrm{a}$ & $19.8 \mathrm{~b}$ & 199.9 a & $53.3 \mathrm{a}$ & $15.6 \mathrm{~b}$ & $4.1 \mathrm{~b}$ & $0.14 \mathrm{~b}$ & $0.18 \mathrm{~b}$ & $0.05 \mathrm{~b}$ & $0.31 \mathrm{ab}$ \\
\hline o & & & & & & & & & & & & & \\
\hline
\end{tabular}

${ }^{\mathrm{z}}$ Cover crops were planted in the previous fall. Biomass was measured before winter. Data were combined for 2 years in each experiment. The measured plant nutrients were nitrogen $(\mathrm{N})$, phosphorus $(\mathrm{P})$, potassium $(\mathrm{K})$, magnesium $(\mathrm{Mg})$, calcium $(\mathrm{Ca})$, sulfur $(\mathrm{S})$, sodium $(\mathrm{Na})$, iron $(\mathrm{Fe})$, manganese $(\mathrm{Mn})$, boron $(\mathrm{B})$, copper $(\mathrm{Cu})$, and zinc $(\mathrm{Zn})$. $\mathrm{l} \mathrm{kg} \cdot \mathrm{ha}^{-1}=0.8922 \mathrm{lb} /$ acre.

${ }^{y}$ All numbers within a column followed by the same letter are not statistically different at a probability level of 0.05 . 
Table 3. Soil nutrient content at onion planting in Laingsburg, MI, as affected by the preceding cover crop treatment in the 2005 and 2006 growing seasons. ${ }^{\mathrm{z}}$

\begin{tabular}{|c|c|c|c|c|c|c|}
\hline Treatment & $\begin{array}{c}\mathrm{N} \\
\left(\mathrm{mg} \cdot \mathrm{kg}^{-1}\right)^{\mathrm{y}}\end{array}$ & $\begin{array}{c}\text { P - weak bray } \\
\left(\mathrm{mg} \cdot \mathrm{kg}^{-1}\right)^{\mathrm{y}}\end{array}$ & $\begin{array}{c}\mathrm{K} \\
\left(\mathrm{mg} \cdot \mathrm{kg}^{-1}\right)^{\mathrm{y}}\end{array}$ & $\begin{array}{c}\mathrm{Mg} \\
\left(\mathrm{mg} \cdot \mathrm{kg}^{-1}\right)^{\mathrm{y}}\end{array}$ & $\begin{array}{c}\mathrm{Ca} \\
\left(\mathrm{mg} \cdot \mathrm{kg}^{-1}\right)^{\mathrm{y}}\end{array}$ & $\begin{array}{c}\text { CEC } \\
(\mathrm{meq} / 100 \mathrm{~g})^{\mathrm{y}}\end{array}$ \\
\hline Brown mustard & $26.5 a^{x}$ & $43.6 \mathrm{~b}$ & $392.8 \mathrm{a}$ & $819.0 \mathrm{a}$ & $5702.0 \mathrm{a}$ & $39.1 \mathrm{a}$ \\
\hline Oilseed radish & $27.4 \mathrm{a}$ & $50.1 \mathrm{a}$ & $431.1 \mathrm{a}$ & $806.8 \mathrm{a}$ & $5725.5 \mathrm{a}$ & $39.2 \mathrm{a}$ \\
\hline Oriental mustard & $27.5 \mathrm{a}$ & $45.3 \mathrm{~b}$ & $436.0 \mathrm{a}$ & $823.0 \mathrm{a}$ & $5799.1 \mathrm{a}$ & $39.8 \mathrm{a}$ \\
\hline Yellow mustard & $27.6 \mathrm{a}$ & $45.5 \mathrm{~b}$ & $417.9 \mathrm{a}$ & $821.0 \mathrm{a}$ & $5761.3 \mathrm{a}$ & $39.7 \mathrm{a}$ \\
\hline Sorghum sudangrass & $26.6 \mathrm{a}$ & $45.5 \mathrm{~b}$ & $367.8 \mathrm{a}$ & $769.8 \mathrm{a}$ & $5307.4 \mathrm{a}$ & $35.9 \mathrm{a}$ \\
\hline
\end{tabular}

${ }^{z}$ Cover crops were planted and incorporated the previous fall. Soil samples were collected the following April. Data were combined for 2005 and 2006 . The measured soil nutrients were nitrogen $(\mathrm{N})$, phosphorus $(\mathrm{P})$, potassium $(\mathrm{K})$, magnesium $(\mathrm{Mg})$, and calcium $(\mathrm{Ca})$, and cation exchange capacity $(\mathrm{CEC})$.

$1 \mathrm{mg} \cdot \mathrm{kg}^{-1}=1 \mathrm{ppm}, 1 \mathrm{meq} / 100 \mathrm{~g}=1 \mathrm{cmol} \cdot \mathrm{kg}^{-1}$.

${ }^{x}$ All numbers within a column followed by the same letter are not statistically different at a probability level of 0.05 .

Table 4. Effects of the preceding cover crop on weed density and biomass during onion growth in Laingsburg, MI, in 2005 and $2006 .{ }^{\mathrm{z}}$

\begin{tabular}{lccccccc}
\hline & \multicolumn{3}{c}{ Weed density $\left(\mathrm{plant} / \mathrm{m}^{2}\right)^{\mathrm{y}}$} & & \multicolumn{3}{c}{ Weed biomass $\left(\mathrm{g} \cdot \mathbf{m}^{-2}\right)^{\mathrm{y}}$} \\
\cline { 2 - 4 } Cover crop & Sample 1 & Sample 2 & Total & & Sample 1 & Sample 2 & Total \\
\hline Brown mustard & $60.8 \mathrm{~b}^{\mathrm{x}}$ & $34.0 \mathrm{c}$ & $94.8 \mathrm{bc}$ & & $10.9 \mathrm{ab}$ & $4.9 \mathrm{bc}$ & $15.8 \mathrm{ab}$ \\
Oilseed radish & $71.3 \mathrm{~b}$ & $47.1 \mathrm{bc}$ & $118.4 \mathrm{bc}$ & & $11.2 \mathrm{a}$ & $4.3 \mathrm{c}$ & $15.5 \mathrm{ab}$ \\
Oriental mustard & $61.4 \mathrm{~b}$ & $39.6 \mathrm{bc}$ & $101.0 \mathrm{bc}$ & & $8.0 \mathrm{ab}$ & $7.2 \mathrm{a}$ & $15.2 \mathrm{ab}$ \\
Yellow mustard & $48.4 \mathrm{~b}$ & $34.6 \mathrm{bc}$ & $83.0 \mathrm{c}$ & & $5.9 \mathrm{~b}$ & $4.9 \mathrm{bc}$ & $10.7 \mathrm{~b}$ \\
Sorghum sudangrass & $76.1 \mathrm{ab}$ & $50.9 \mathrm{~b}$ & $127.0 \mathrm{~b}$ & & $11.3 \mathrm{a}$ & $6.8 \mathrm{ab}$ & $18.1 \mathrm{a}$ \\
Control & $102.5 \mathrm{a}$ & $72.6 \mathrm{a}$ & $175.1 \mathrm{a}$ & & $8.7 \mathrm{ab}$ & $7.1 \mathrm{a}$ & $15.8 \mathrm{ab}$ \\
\hline
\end{tabular}

${ }^{\mathrm{z}}$ Cover crops were planted and incorporated the previous fall. Weed sample 1 and sample 2 were taken on 23 June and 7 July in 2005, and 26 June and 7 July in 2006 during onion growth. This corresponded to 55 and $69 \mathrm{~d}$ after onion seeding in 2005, and 61 and $75 \mathrm{~d}$ after onion seeding in 2006. Data for 2005 and 2006 were combined. ${ }^{y} l$ plant $/ \mathrm{m}^{2}=0.0929$ plant $/ \mathrm{ft}^{2} ; \mathrm{l} \mathrm{g} \cdot \mathrm{m}^{-2}=0.0033 \mathrm{oz} / \mathrm{ft}^{2}$

xAll numbers within a column followed by the same letter are not statistically different at a probability level of 0.05 .

Table 5. Effect of the preceding cover crop on weed density by species in onion in Laingsburg, MI, in 2005 and $2006 .^{\mathrm{z}}$

\begin{tabular}{lclcrc}
\hline & \multicolumn{5}{c}{ Weed density $\left(\text { plant } / \mathbf{m}^{2}\right)^{\mathrm{y}}$} \\
\cline { 2 - 6 } Treatment & $\begin{array}{c}\text { Yellow } \\
\text { nutsedge }\end{array}$ & $\begin{array}{c}\text { Common } \\
\text { purslane }\end{array}$ & $\begin{array}{c}\text { Redroot } \\
\text { pigweed }\end{array}$ & $\begin{array}{c}\text { Wild } \\
\text { mustard }\end{array}$ & $\begin{array}{c}\text { Other } \\
\text { species }\end{array}$ \\
\hline Brown mustard & $20.0 \mathrm{ab}^{\mathrm{x}}$ & $41.3 \mathrm{abc}$ & $16.3 \mathrm{bc}$ & $9.8 \mathrm{a}$ & $7.5 \mathrm{a}$ \\
Oilseed radish & $17.4 \mathrm{~b}$ & $38.5 \mathrm{abc}$ & $25.6 \mathrm{~b}$ & $27.4 \mathrm{a}$ & $9.5 \mathrm{a}$ \\
Oriental mustard & $14.5 \mathrm{~b}$ & $37.1 \mathrm{bc}$ & $12.3 \mathrm{bc}$ & $28.5 \mathrm{a}$ & $8.6 \mathrm{a}$ \\
Yellow mustard & $15.5 \mathrm{~b}$ & $23.9 \mathrm{c}$ & $8.0 \mathrm{c}$ & $27.4 \mathrm{a}$ & $8.3 \mathrm{a}$ \\
Sorghum sudangrass & $30.0 \mathrm{a}$ & $51.1 \mathrm{ab}$ & $26.9 \mathrm{~b}$ & $10.5 \mathrm{a}$ & $8.5 \mathrm{a}$ \\
Control & $11.3 \mathrm{~b}$ & $56.8 \mathrm{a}$ & $79.0 \mathrm{a}$ & $19.6 \mathrm{a}$ & $8.5 \mathrm{a}$ \\
\hline
\end{tabular}

${ }^{\mathrm{z}}$ Cover crops were sown and incorporated previous fall. Weed sample 1 and sample 2 were taken on 23 June and 7 July in 2005, and 26 June and 7 July in 2006 during onion growth. This corresponded to 55 and $69 \mathrm{~d}$ after onion seeding in 2005, and 61 and $75 \mathrm{~d}$ after onion seeding in 2006. Within each year, data from both sampling dates were averaged. Data were combined for 2 years in each experiment.

${ }^{\mathrm{y}} 1$ plant $/ \mathrm{m}^{2}=0.0929 \mathrm{plant} / \mathrm{ft}^{2}$.

${ }^{x}$ All numbers within a column followed by the same letter are not statistically different at a probability level of 0.05 .

greater onion stand counts compared with the control treatment (Fig. 2). Oilseed radish and yellow mustard had onion plant numbers greater by $14.6 \%$ and $12.5 \%$ respectively compared with the control. Oilseed radish increased onion marketable yield by $9.4 \%$ and bulb number by $16.5 \%$ compared with the control treatment (Table 6). Brown mustard, yellow mustard, and sorghum sudangrass also increased bulb number, but the increased bulb number did not translate into significant increases in total weight.

The cover crops significantly affected onion size distribution (Table 6). There were more grade 1 onions (small nonmarketable) in the cover crop treatments compared with the control except for the oilseed radish treatment. This was likely a direct consequence of better stand establishment in the cover crop plots compared with the control plots. Oilseed radish and brown mustard treatments also had a larger number and greater weight of grade 2 bulbs compared with the control treatment. Grade 3 and grade 4 onions were unaffected by the cover crop treatment.

\section{Discussion}

Brassica species are promising cover crops in agricultural systems because, in addition to their general role as cover crops, they produce chemicals with activity on a broad range of soil-borne pests and diseases (Haramoto and Gallandt, 2004; Matthiessen and Kirkegaard, 2006). Nutrient cycling in this study showed that brassica cover crops, when planted in the Great Lakes region (temperate climate) in the fall, can produce large amounts of biomass and, therefore, can recycle significant amounts of nutrients. Our study also showed that the amount of $\mathrm{Mg}, \mathrm{Ca}$, $S$, and some other micronutrients recycled in brassica cover crops was different from sorghum sudangrass.

Despite the large amount of nutrients in the cover crop biomass, soil nutrient levels were generally similar in all treatments, regardless of whether cover crops were used. The lack of difference in soil fertility between the cover crops and the control was likely because weeds were allowed to grow in the control plots. These weeds were able to recycle some nutrients, like the cover crops, but with the downside of producing seeds that would become problematic the following season. During soil 


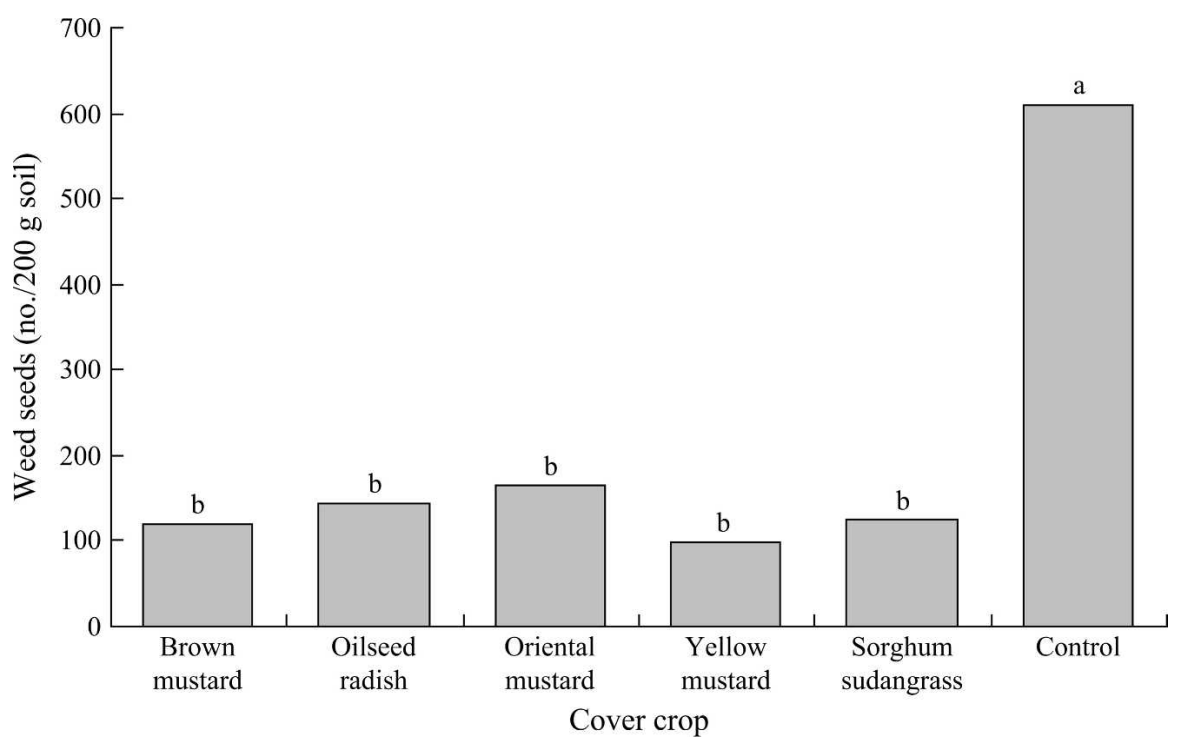

Fig. 1. Effects of the cover crops on the number of weed seed in the soil the following spring. Cover crops were planted and incorporated in the fall, and soil samples were taken the following April before onion planting. Data were combined for 2005 and 2006. Bars with the same letter are not significantly different at the $5 \%$ level of probability. 1 seed $/ 200 \mathrm{~g}=0.1417 \mathrm{seed} / \mathrm{oz}$.

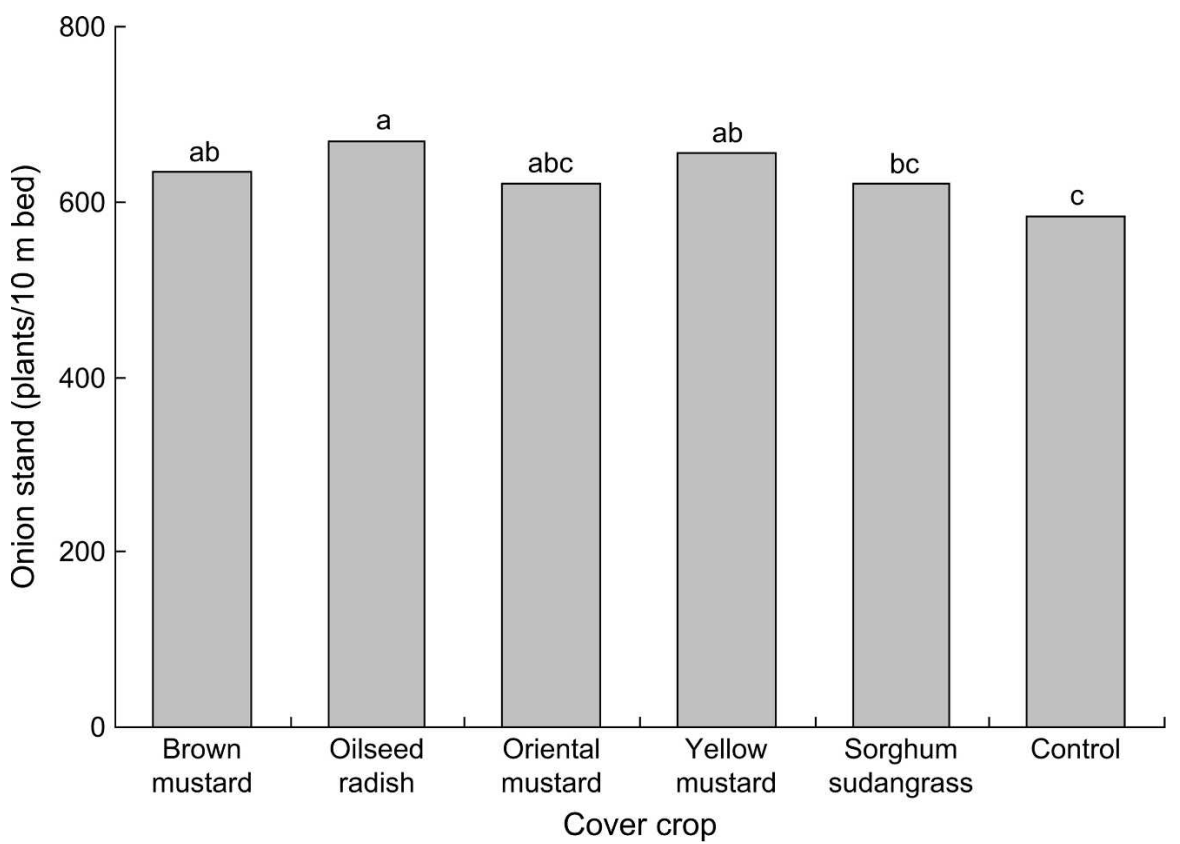

Fig. 2. Onion stand count as affected by the preceding cover crop. The cover crops were planted and incorporated the previous fall. Onion plant number was counted 2 weeks after emergence. Data were combined for 2005 and 2006. Bars with the same letter are not significantly different at the $5 \%$ level of probability. 1 plant $/ 10 \mathrm{~m}=0.0305$ plant $/ \mathrm{ft}$.

sampling, there was still a significant amount of crop residues seen in the field because of the slow decomposition during the winter. Nutrients trapped in these residues will be available to onion after decomposition. In a previous study using oilseed radish in a celery field, Charles (2005) showed large amount of nutrients studies evaluating the nutrient cycling potential of cover crops should take into account the rate of residue decomposition and nutrient release.

In our study, all cover crops reduced the number of weed seed in the soil and reduced, subsequently, weed density and biomass in the succeeding onion crop compared with the control treatment. Yellow mustard had the greatest effect on weed suppression. This result is consistent with previous findings on brassica cover crops (Al-Khatib et al., 1997; Boydston and Hang, 1995; Krishnan et al., 1998). Brassica species and brassica residues have been reported to suppress seed germination, emergence, and seedling growth in many laboratory and greenhouse studies (Haramoto and Gallandt, 2004). AlKhatib et al. (1997) showed that weed density in pea (Pisum sativum) following rapeseed (Brassica napus) and white mustard (Sinapis alba) was lower than following wheat. Boydston and Hang (1995) showed that after rapeseed, midseason weed density in potato decreased and potato yield increased compared with systems in which the ground was previously bare or in sorghum sudangrass. Krishnan et al. (1998) showed weed biomass in soybean (Glycine max) following rapeseed, white mustard, and brown mustard was lower than the control at one of the two locations tested.

Surprisingly, sorghum sudangrass had the highest yellow nutsedge density: 1.7 times higher than in the control treatment. The reason for the increased yellow nutsedge density is unknown and may need further attention in future studies. Despite the high level of weed suppression by the cover crops, it is important to note that this effect was not enough to eliminate normal weed control programs. Similar results have been reported by Boyhan et al. (2006) with natural mulches for organic onion production. They tested a variety of natural mulches and found that none of them was effective enough to be used as a standalone weed management tool. It is therefore clear that cover crops or mulches when used for weed suppression should be combined with existing management strategies. Continuous use of the cover crops in combination with other management methods like hand weeding 
Table 6. Effect of the preceding cover crop on onion marketable yield and grade distribution in 2005 and $2006 .{ }^{\mathrm{z}}$

\begin{tabular}{|c|c|c|c|c|c|c|c|c|c|c|}
\hline \multirow[b]{2}{*}{ Cover crop } & \multicolumn{2}{|c|}{ Grade $1^{y}$} & \multicolumn{2}{|c|}{ Grade 2} & \multicolumn{2}{|c|}{ Grade 3} & \multicolumn{2}{|c|}{ Grade 4} & \multicolumn{2}{|c|}{ Marketable yield } \\
\hline & $\begin{array}{c}\text { No. } \\
(1000 / \mathrm{ha})^{\mathrm{x}}\end{array}$ & $\begin{array}{c}\mathrm{Wt} \\
\left(\mathrm{t} \cdot \mathrm{h} \mathbf{a}^{-1}\right)^{\mathrm{x}}\end{array}$ & $\begin{array}{c}\text { No. } \\
(1000 / \mathrm{ha})\end{array}$ & $\begin{array}{c}\mathrm{Wt} \\
\left(\mathrm{t} \cdot \mathrm{ha}^{-1}\right)\end{array}$ & $\begin{array}{c}\text { No. } \\
(1000 / \text { ha })\end{array}$ & $\begin{array}{c}W t \\
\left(t \cdot h a^{-1}\right)\end{array}$ & $\begin{array}{c}\text { No. } \\
(1000 / \text { ha })\end{array}$ & $\begin{array}{c}\mathrm{Wt} \\
\left(\mathrm{t} \cdot \mathrm{ha}^{-1}\right)\end{array}$ & $\begin{array}{c}\text { No. } \\
(1000 / \text { ha })\end{array}$ & $\begin{array}{c}\mathrm{Wt} \\
\left(\mathrm{t} \cdot \mathrm{ha}^{-1}\right)\end{array}$ \\
\hline Oriental mustard & $133.8 \mathrm{a}$ & $6.4 \mathrm{a}$ & 293.8 bc & $33.5 \mathrm{ab}$ & $71.0 \mathrm{a}$ & $13.0 \mathrm{a}$ & $12.5 \mathrm{a}$ & $3.4 \mathrm{a}$ & $377.21 \mathrm{bc}$ & $49.92 \mathrm{ab}$ \\
\hline Yellow mustard & $116.9 \mathrm{a}$ & $5.9 \mathrm{a}$ & $315.4 \mathrm{abc}$ & $35.3 \mathrm{ab}$ & $82.0 \mathrm{a}$ & $15.4 \mathrm{a}$ & $12.1 \mathrm{a}$ & $3.2 \mathrm{a}$ & $409.56 \mathrm{ab}$ & $53.87 \mathrm{ab}$ \\
\hline Brown mustard & $127.6 \mathrm{a}$ & $6.1 \mathrm{a}$ & $350.4 \mathrm{a}$ & $36.6 \mathrm{a}$ & $75.0 \mathrm{a}$ & $13.7 \mathrm{a}$ & $9.2 \mathrm{a}$ & $2.4 \mathrm{a}$ & $434.56 \mathrm{a}$ & $52.69 \mathrm{ab}$ \\
\hline
\end{tabular}

${ }^{2}$ The cover crops were planted in previous fall, and onion was sown the following spring.

Grades $1,2,3$, and 4 consisted of bulbs with a diameter of 0 to 2 inches, 2 to 2.5 inches, 2.5 to 3 inches, and more than 3 inches respectively. 1 inch = 25.4 mm.

${ }^{\mathrm{x}} 1000$ onions $/ \mathrm{ha}=404.7$ onions $/ \mathrm{acre} ; \mathrm{l} \mathrm{t} \cdot \mathrm{ha}^{-1}=0.446 \mathrm{l}$ ton $/$ acre

wAll numbers within a column and year followed by the same letter are not statistically different $(\alpha=0.05)$.

or herbicide application would improve long-term weed management (Liebman and Gallandt, 1997).

Oilseed radish increased onion yield. Similar results were observed in potato following rapeseed, and in soybean following three brassica cover crops (Boydston and Hang, 1995; Krishnan et al., 1998). However, yield losses were reported in peas following rapeseed and white mustard as a result of a reduction in crop stand (Al-Khatib et al., 1997; Muehlchen et al., 1990; Scott and Knudsen, 1999). In our study, oilseed radish and yellow mustard increased the onion stand count by $14.6 \%$ and $12.5 \%$, and had the highest onion yield among the treatments. The improved onion stand in the cover crop treatments had little effect on marketable yield, but affected bulb size distribution. Bulb size distribution is an important factor for determining onion economic value. Under Michigan conditions, growers are interested in large bulbs. In this study, yield of large bulbs (grades 3 and 4 ) was unaffected by the cover crop treatments. Culls (grade 1) were the most affected, with cover crop plots producing more small bulbs. This was likely the direct consequence of the increased stand in the cover crops. In New York, sorghum sudangrass was also reported to improve onion stand (Mishanec, 2005). The processes underlying the increased onion stand following the cover crops is not known, but could be related to soil biological properties. Future investigations should look at soil microbial communities and onion seed germination in the different systems. Michigan growers have also expressed interest in testing the possibility to reduce onion planting density after the brassica cover crops. If proved effective, even a $10 \%$ reduction in seeding rate could provide enough incentive to growers and cover some of the cost associated with the use of cover crops.

In conclusion, the cover crops tested appear to be promising for direct-seeded onion production in muck soils under our climatic conditions. Benefits could include enhanced nutrient cycling (and thus reduced nutrient leaching), some level of weed suppression, and enhanced yield. Integrating the cover crops into onion production systems could also enhance the sustainability of the current short-term onion rotations.

\section{Literature cited}

Al-Khatib, K., C. Libbey, and R. Boydston. 1997. Weed suppression with brassica green manure crops in green pea. Weed Sci. 45:439-445

Boydston, R. and A. Hang. 1995. Rapeseed (Brassica napus) green manure crop suppresses weeds in potato (Solanum tuberosum). Weed Technol. 9:669675.

Boyhan, G.E., R. Hicks, and C.R. Hill. 2006. Natural mulches are not very effective for weed control in onions. HortTechnology 16:523-526.

Brown, P.D. and M.J. Morra. 1996. Hydrolysis products of glucosinolates in Brassica napus tissues as inhibitors of seed germination. Plant Soil 181:307-316.

Charles, K.S. 2005. Celery (Apium Graveolens L.) and weed response to cover crops and nutrient management on muck soil. Michigan State University, East Lansing, MI, MS thesis.

Charles, K.S., M. Ngouajio, D.D. Warncke, K.L. Poff, and M.K. Hausbeck.
2006. Integration of cover crops and fertilizer rates for weed management in celery. Weed Sci. 54:326-334.

Corak, S.J., W.W. Frye, and M.S. Smith. 1991. Legume mulch and nitrogen fertilizer effects on soil water and corn production. Soil Sci. Soc. Amer. J. 55: 1395-1400.

Greenland, R.G. 2000. Optimum height at which to kill barley used as a living mulch in onions. HortScience 35:853855 .

Greenwood, D.J., C.R. Rahn, A. Draycott, L.V. Vaidyanathan, and C.D. Paterson. 1996. Modeling and measurement of the effects of fertilizer- $\mathrm{N}$ and crop residue incorporation on $\mathrm{N}$-dynamics in vegetable cropping. Soil Use Mgt. 12:13-24.

Gross, K.L. 1990. A comparison of methods for estimating seed numbers in the soil. J. Ecol. 78:1079-1093.

Hall, J.K., N.L. Hartwig, and L.D. Hoffman. 1984. Cyanazine losses in runoff from no-tillage corn in "living mulch" and dead mulches vs. unmulched conventional tillage. J. Environ. Qual. 13: $105-110$.

Haramoto, E.R. and E.R. Gallandt. 2004. Brassica cover cropping for weed management: A review. Renewable Agr. Food Systems 19:187-198.

Haramoto, E.R. and E.R. Gallandt. 2005. Brassica cover cropping: II. Effects on growth and interference of green bean (Phaseolus vulgaris) and redroot pigweed (Amaranthus retroflexus). Weed Sci. 53:702-708.

Hatterman-Valenti, H.M. and P.E. Hendrickson. 2006. Companion crop and planting configuration effect on onion. HortTechnology 16:12-15.

Hoffmann, M.P., C.H. Petzoldt, and A.C. Frodsham. 1996. Integrated pest management for onions. A Cornell Coop. Ext. publ. no. 119. Cornell Univ., Ithaca, NY. 


\section{Research Reports}

Krishnan, G., D.L. Holshouser, and S.J. Nissen. 1998. Weed control in soybean (Glycine max) with green manure crops. Weed Technol. 12:97-102.

Liebman, M. and E.R. Gallandt. 1997. Many little hammers: Ecological management of crop-weed interactions, p. 291343. In: L.E. Jackson (ed.). Ecology in agriculture. Academic Press, San Diego, CA.

Matthiessen, J.N. and J.A. Kirkegaard. 2006. Biofumigation and enhanced biodegradation: Opportunity and challenge in soilborne pest and disease management. Crit. Rev. Plant Sci. 25:235-265.

Michigan Department of Agriculture. 2006. Michigan agricultural statistics 2005-2006. Michigan Department of Agriculture, East Lansing, MI.

Mishanec, J. 2005. Onion rotational strategies. Great Lakes Fruit, Vegetable, and Farm Market Expo. 2 Apr. 2007. $<$ www.glexpo.org/abstracts / 2005abstracts/onion.pdf>.
Mojtahedi, H., G.S. Santo, A.N. Hang, and J.H. Wilson. 1991. Suppression of root-knot nematode populations with selected rapeseed cultivars as green manure. J. Nematol. 23:170-174.

Muehlchen, A., R. Rand, and J. Parke. 1990. Evaluation of crucifer green manures for controlling aphanomyces root rot of peas. Plant Dis. 74:651-654.

Mutch, D.R. and T.E. Martin. 1998. Cover crops, p. 44-53. In: M.A. Cavigelli, S.R. Deming, L.K. Probyn, and R.R. Harwood (eds.). Michigan Field Crop Ecology: Managing Biological Processes for Productivity and Environmental Quality. Extension Bulletin E-2646, Michigan State Univ., East Lansing, Mich.

Rosecrance, R.C., G.W. McCarty, D.R Shelton, and J.R. Teasdale. 2000. Denitrification and $\mathrm{N}$ mineralization from hairy vetch (Vicia villosa Roth) and rye (Secale cereale L.) cover crop monocultures and bicultures. Plant Soil 227:283290.
Scott, J. and G. Knudsen. 1999. Soil amendment effects of rape (Brassica napus) residues on pea rhizosphere bacteria. Soil Biol. Biochem. 31:1435-1441.

Thorup-Kristensen, K. 2006. Root growth and nitrogen uptake of carrot, early cabbage, onion and lettuce following a range of green manures. Soil Use Mgt. 22:29-38.

U.S. Department of Agriculture. 1995. United States standards for grades of Bermuda-Granex-Grano type onions. Effective 10 Oct. 1995 (reprinted Jan. 1997). 2 Apr. 2007. <www.ams.usda. gov/standards/onsbgg.pdf $>$.

Zandstra, B.H. 2005. 2006 Weed control guide for commercial vegetable crops. Extension bulletin E-433, Michigan State University, East Lansing, MI.

Zandstra, B.H. and D.D. Warncke. 1993. Interplanted barley and rye in carrots and onions. HortTechnology 3:214-218. 